\title{
Adsorptive stripping voltammetry for simultaneous determination of hydrochlorothiazide and triamterene in hemodialysis samples using a multi-walled carbon nanotube-modified glassy carbon electrode
}

\author{
Felipe Fantinato Hudari*, João Carlos Souza, Maria Valnice Boldrin Zanoni \\ Universidade Estadual Paulista (UNESP), Instituto de Química, Araraquara, Brazil
}

\section{A R T I C L E I N F O}

\section{Keywords:}

Sensor

Modified electrode

Voltammetric method

Diuretic

Stripping voltammetry

\begin{abstract}
A B S T R A C T
Hemodialysis is the most commonly used method for the treatment of chronic kidney disease. In this procedure, some patients use diuretics to control weight gain and blood pressure. In this work, a voltammetric sensor based on a glassy carbon electrode modified with carbon nanotubes (GCE/MWCNT) is described for the simultaneous determination of the diuretics hydrochlorothiazide (HCT) and triamterene (TRT). The oxidation of the diuretics on the GCE/MWCNT surface was observed at 1.01 and $1.17 \mathrm{~V}$ for HCT and TRT, respectively, allowing simultaneous determination, which was not possible with the unmodified glassy carbon electrode. The GCE/ MWCNT electrode provided 6-fold and 10-fold gains in anode peak intensity for HCT and TRT, respectively, compared to the unmodified electrode. After optimization of the conditions $(\mathrm{pH}$, accumulation time, and accumulation potential), analytical curves were constructed for the analytes in the range from $1.0 \times 10^{-7}$ to 2.0 $\times 10^{-5} \mathrm{~mol} \mathrm{~L}^{-1}$. The detection limits for HCT and TRT were $2.8 \times 10^{-8}$ and $2.9 \times 10^{-8} \mathrm{~mol} \mathrm{~L}^{-1}$, respectively. A high performance liquid chromatography method with diode array detection was also developed for the determination of HCT and TRT in hemodialysis samples, for comparison with the electroanalytical method.
\end{abstract}

\section{Introduction}

Hemodialysis is a treatment for chronic kidney disease (CKD), which affects $10 \%$ of the world's population [1,2]. Ensuring the quality of dialysis water can be a challenge, since each patient is exposed to between 18,000 and 36,0001 of water per year [3], and high water quality is extremely important in order to avoid exposure of these individuals to chemical and microbial contaminants [4]. The literature reports several analytical methods for the detection of metal contaminants, with the aim of minimizing the possibility of patient exposure [5-8]. However, to the best of our knowledge, there have been no reported studies concerning the detection of pharmaceutical compounds such as diuretics in the water used for dialysis. The control of diuretics is important, since these drugs may be used as part of the hemodialysis treatment, in order to control weight gain and blood pressure [9]. Therefore, it is necessary to develop methods able to detect and quantify diuretics such as hydrochlorothiazide (HCT) and triamterene (TRT) in samples of hemodialysis water.

Methods have been reported for the determination of HCT and TRT based on chromatography [10,11], spectrophotometry [12], capillary electrophoresis [13], amperometry [14], and voltammetry [15,16]. In addition to the need for methods for the determination of these diuretics, in recent years increasing attention has been given to the development of green analytical methods, with the goal of reducing environmental pollution [17].

Electrochemical analytical techniques are attractive because in addition to avoiding the generation of large amounts of residues, they offer high sensitivity, good reproducibility, low cost, and the possibility of miniaturization [18-22]. Further improvements in these techniques in terms of sensitivity, selectivity, enhanced surface area, and catalytic effects can be achieved by modifying the surfaces of the electrodes with specific materials [23-26]. Multi-walled carbon nanotubes (MWCNT), first discovered in 1991 [27], are especially attractive as electrode modifiers, due to their excellent electronic, thermal, mechanical, and catalytic properties $[28,29]$. From the electrochemical perspective, their use increases the active area and improves electron transfer reactions, resulting in higher detection capability and better peak separation $[30,31]$.

This work describes the development of an electrochemical sensor based on a glassy carbon electrode modified with carbon nanotubes for the simultaneous determination of hydrochlorothiazide and triamterene at very low concentration in hemodialysis water, synthetic urine,

\footnotetext{
* Corresponding author.

E-mail address: felipe_fhudari@hotmail.com (F.F. Hudari).
} 
and other aqueous samples of environmental interest. In addition, a high performance liquid chromatography method with diode array detection (HPLC-DAD) was developed for determination of the compounds, and the figures of merit were compared to those for the proposed electrochemical sensor.

\section{Experimental}

\subsection{Reagents and equipment}

All chemicals used in this work were analytical grade and the solutions were prepared using ultra-pure water (Milli- ${ }^{\circ}$ system, Millipore). Triamterene (purity $\geq 99.9 \%$ ), hydrochlorothiazide, and dimethylsulfoxide were obtained from Sigma-Aldrich. Acetic acid, phosphoric acid, boric acid, and potassium chloride were from Merck. Sodium hydroxide and N,N-dimethylformamide were from Synth. Multi-walled carbon nanotubes (MWCNT) were obtained from DropSens. Standard solutions of $0.01 \mathrm{~mol} \mathrm{~L}^{-1}$ triamterene and hydrochlorothiazide were prepared by dissolution of the compounds in dimethylsulfoxide and acetonitrile, respectively, and were subsequently diluted in $0.10 \mathrm{~mol} \mathrm{~L}^{-1}$ Britton-Robinson $(\mathrm{B}-\mathrm{R})$ buffer, used as supporting electrolyte. The $\mathrm{B}-\mathrm{R}$ buffer was prepared by mixing appropriate amounts of $0.10 \mathrm{~mol} \mathrm{~L}^{-1}$ sodium hydroxide with orthophosphoric acid, acetic acid, and boric acid (all at $0.10 \mathrm{~mol} \mathrm{~L}^{-1}$ ). Measurements of $\mathrm{pH}$ were performed with a Tecnopon mPA $210 \mathrm{pH}$ meter. The electrochemical experiments (using voltammetric techniques and electrochemical impedance spectroscopy) employed an Autolab PGSTAT $302 \mathrm{~N}$ potentiostat equipped with a FRA32 AC module and controlled using NOVA software. The chromatographic analyses were performed using a Shimadzu LC10ATVp high performance liquid chromatograph equipped with a diode array detector (HPLC-DAD) and controlled using CLASS-VP software.

\subsection{Preparation of the modified electrode}

A $1 \mathrm{mg}$ portion of MWCNT was macerated in a Petri dish for $15 \mathrm{~min}$ and was then placed in $1 \mathrm{~mL}$ of $\mathrm{N}, \mathrm{N}$-dimethylformamide, with ultrasonication for $30 \mathrm{~min}$. A $2.5 \mu \mathrm{L}$ aliquot of the resulting MWCNT composite was placed on the surface of a previously cleaned glassy carbon electrode, followed by drying of the film at $60{ }^{\circ} \mathrm{C}$ for $20 \mathrm{~min}$ in an oven.

\subsection{Sample preparation and analysis}

\subsubsection{Tap water sample}

An aliquot of tap water fortified with HCT and TRT was transferred to a $10 \mathrm{~mL}$ electrochemical cell, giving a final concentration of $3 \mu \mathrm{mol} \mathrm{L}^{-1}$ of the diuretics. Voltammograms were recorded in $0.10 \mathrm{~mol} \mathrm{~L}^{-1} \mathrm{~B}-\mathrm{R}$ buffer ( $\mathrm{pH} 4.0$ ), under magnetic stirring, using linear sweep adsorptive stripping voltammetry with application of an accumulation potential of $0.80 \mathrm{~V}$ for $40 \mathrm{~s}$. The concentrations of HCT and TRT were obtained using the standard additions method.

\subsubsection{Water treatment plant sample}

A $10 \mathrm{~mL}$ sample of water collected from a water treatment plant in the city of Araraquara (São Paulo State) was fortified with $15 \mu \mathrm{mol} \mathrm{L}{ }^{-1}$ of HCT and TRT. A $2 \mathrm{~mL}$ aliquot of the sample was transferred to an electrochemical cell containing $8 \mathrm{~mL}$ of B-R buffer solution, resulting in final concentrations of $3 \mu \mathrm{mol} \mathrm{L}^{-1}$ of the diuretics, and analysis was performed as described in Section 2.3.1.

\subsubsection{Artificial urine sample}

The artificial urine sample was prepared by mixing the following reagents in $250 \mathrm{~mL}$ of water: $0.73 \mathrm{~g} \mathrm{NaCl}, 0.40 \mathrm{~g} \mathrm{KCl}, 0.28 \mathrm{~g}$ $\mathrm{CaCl}_{2} \cdot 2 \mathrm{H}_{2} \mathrm{O}, 0.56 \mathrm{~g} \mathrm{Na}_{2} \mathrm{SO}_{4}, 0.35 \mathrm{~g} \mathrm{KH}_{2} \mathrm{PO}_{4}, 0.25 \mathrm{~g} \mathrm{NH}_{4} \mathrm{Cl}$, and $6.25 \mathrm{~g}$ urea $[32,33]$. A $10 \mathrm{~mL}$ aliquot was then fortified with $8.40 \times 10^{-7}$ and $9.87 \times 10^{-7} \mathrm{~mol} \mathrm{~L}^{-1}$ of HCT and TRT, respectively (equivalent to
$250 \mathrm{ng} \mathrm{mL}^{-1}$ ). For the electrochemical analysis, $4 \mathrm{~mL}$ of the urine sample, without any previous treatment, was placed in an electro-

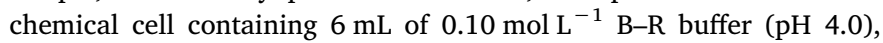
resulting in concentrations of $3.36 \times 10^{-7}$ and $3.95 \times 10^{-7} \mathrm{~mol} \mathrm{~L}^{-1}$ of HCT and TRT, respectively. Analysis was performed as described in Section 2.3.1.

\subsubsection{Hemodialysis sample}

The hemodialysis sample was collected during the hemodialysis of a patient at the Araraquara Regional Hemodialysis Reference Center (São Paulo State). A $10 \mathrm{~mL}$ aliquot was fortified with $15 \mu \mathrm{mol} \mathrm{L}^{-1}$ of HCT and TRT.

For the electroanalytical measurements, a $2 \mathrm{~mL}$ aliquot of the sample (without previous treatment) was placed in an electrochemical cell containing $8 \mathrm{~mL}$ of $0.10 \mathrm{~mol} \mathrm{~L}^{-1} \mathrm{~B}-\mathrm{R}$ buffer ( $\mathrm{pH} 4.0$ ) and was analyzed as described in Section 2.3.1. For measurements using the HPLC-DAD method, the sample was pretreated by filtering first through a $0.45 \mu \mathrm{m}$ filter and then through a $0.22 \mu \mathrm{m}$ filter. The analysis was performed using an injection volume of $20 \mu \mathrm{L}$ of the sample, a Phenomenex Kinetex PFP column $(150 \times 4.6 \mathrm{~mm} ; 5 \mu \mathrm{m})$ heated at $35^{\circ} \mathrm{C}$, and a mobile phase consisting of methanol (eluent A) and $0.01 \mathrm{~mol} \mathrm{~L}^{-1}$ acetate buffer ( $\mathrm{pH} \mathrm{5.6)}$ (eluent B), at a flow rate of $1.2 \mathrm{~mL} \mathrm{~min}^{-1}$. The eluent gradient was as follows: $0-2 \min 5 \% \mathrm{~A}, 2-12 \min 5-100 \% \mathrm{~A}$, 12-14 $\min 100 \%$ A, $14-20 \min 100-5 \%$ A.

\section{Results and discussion}

\subsection{Characteristics of the GCE/MWCNT modified electrode}

Electrochemical impedance spectroscopy (EIS) measurements were recorded using $5 \mathrm{mmol} \mathrm{L}^{-1} \mathrm{Fe}(\mathrm{CN})_{6}{ }^{3-} /{ }^{4-}$ in $0.1 \mathrm{~mol} \mathrm{~L}^{-1} \mathrm{KCl}$. The charge transfer resistance $\left(\mathrm{R}_{\mathrm{ct}}\right)$ of the unmodified GCE was $288 \Omega$ (Fig. 1). After modification of the electrode with MWCNT, $\mathrm{R}_{\mathrm{ct}}$ decreased to $36.2 \Omega$, which could be explained by the excellent intrinsic conductivity of MWCNT. The Nyquist plots for all electrodes were fitted using the Randles circuit (Fig. 1 insert).

\subsection{Electrochemical behavior of HCT and TRT at the GCE/MWCNT electrode}

The electrochemical behaviors of $100 \mu \mathrm{mol} \mathrm{L}^{-1} \mathrm{HCT}$ and TRT were first investigated individually by cyclic voltammetry in $0.10 \mathrm{~mol} \mathrm{~L}^{-1}$ B-R buffer ( $\mathrm{pH}$ 4.0), as shown in Fig. 2. For the glassy carbon electrode (GCE), HCT (Fig. 2.I.a) showed an anodic peak $\left(E_{\mathrm{ap}}\right)$ at $1.06 \mathrm{~V}$, corresponding to oxidation of the -NH- group [34], while no peak was observed in the cathodic scan, indicative of irreversible behavior [35]. For

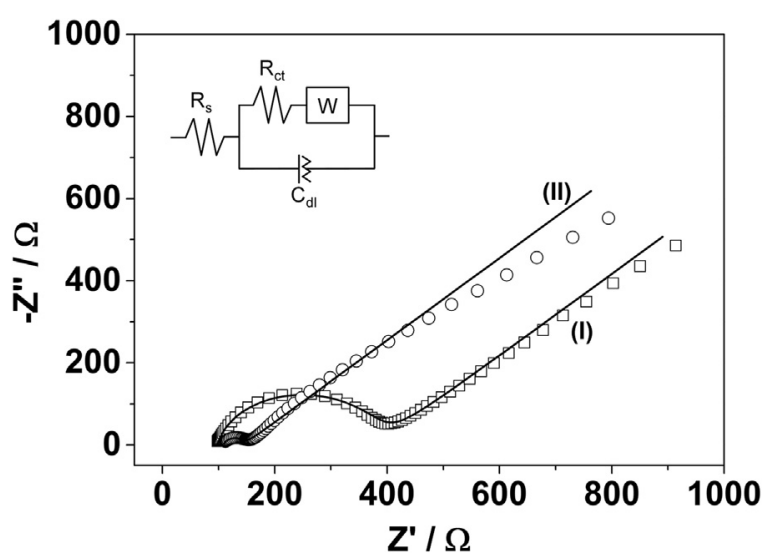

Fig. 1. Nyquist plots using $5.0 \times 10^{-3} \mathrm{~mol} \mathrm{~L}^{-1} \mathrm{Fe}(\mathrm{CN})_{6}{ }^{3-/ 4-}$ redox probes in $1.0 \mathrm{~mol} \mathrm{~L}^{-1} \mathrm{KCl}$ solution for GCE (a) and GCE/MWCNT (b). Conditions: $10 \mathrm{kHz}-0.03 \mathrm{~Hz}$; $5 \mathrm{mV}$ rms sinusoidal modulation at OCP. 

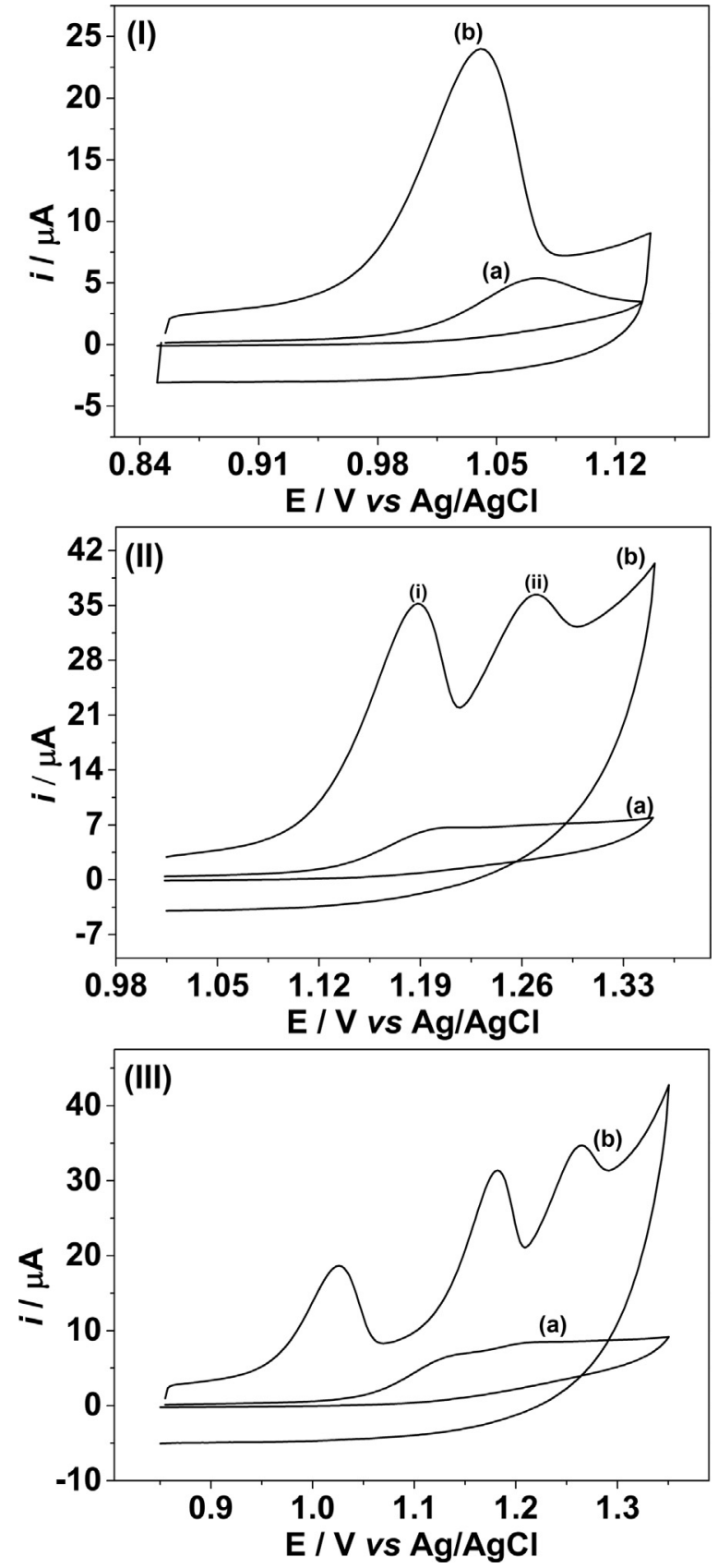

Fig. 2. Cyclic voltammograms for $100 \mu \mathrm{mol} \mathrm{L}^{-1}$ of HCT (I), TRT (II), and HCT + TRT (III) using GCE (a) and GCE/MWCNT (b) in $0.10 \mathrm{~mol} \mathrm{~L}^{-1} \mathrm{~B}-\mathrm{R}$ buffer (pH 4.0). Conditions: $v=75 \mathrm{mV} \mathrm{s}^{-1}$; modifier volume $2.5 \mu \mathrm{L}\left(1 \mathrm{mg} \mathrm{mL}^{-1}\right)$.

oxidation of HCT at the GCE/MWCNT electrode (Fig. 2.I.b), there was a shift of $E_{\text {ap }}$ to $1.01 \mathrm{~V}$ and a 6-fold increase in the anodic peak intensity $\left(i_{\text {ap }}\right)$. In the case of TRT, use of the GCE (Fig. 2.II.a) resulted in a single oxidation peak at $1.21 \mathrm{~V}$, due to oxidation of the $\mathrm{R}-\mathrm{NH}_{2}$ group [15], with irreversible characteristics [35]. At the GCE/MWCNT electrode (Fig. 2.II.b), the $E_{\text {ap }}$ of the $\mathrm{R}-\mathrm{NH}_{2}$ group appeared at $1.17 \mathrm{~V}$ (peak i), with a 10 -fold increase in $i_{\mathrm{pa}}$. In addition, another anodic peak was observed at $1.25 \mathrm{~V}$ (peak ii), which was not found in the scan using the GCE and was probably due to subsequent oxidation of the amine group [36].

For the simultaneous detection of the two compounds at the GCE (Fig. 2.III.a), the oxidation peaks for HCT and TRT were present, but peak overlapping made it impossible to quantify the analytes. However, use of the GCE/MWCNT (Fig. 2.III.b) resulted in separation of the HCT and TRT peaks, with $\Delta \mathrm{E}=160 \mathrm{mV}$, enabling simultaneous determination of the diuretics.

In order to identify the charge transport control in the system, cyclic voltammograms were recorded for oxidation of $100 \mu \mathrm{mol} \mathrm{L}^{-1}$ HCT and TRT in $0.10 \mathrm{~mol} \mathrm{~L}^{-1} \mathrm{~B}-\mathrm{R}$ buffer (pH 4.0), with scanning from 2 to $100 \mathrm{mV} \mathrm{s}^{-1}$ at different rates. As shown in Fig. S1, for HCT (I) and TRT (II), when the scan rate (v) was increased, there were small displacements of the anodic peak potentials $\left(E_{\mathrm{ap}}\right)$ of the two compounds towards more positive regions, which is behavior typical of an irreversible process. The linear relationships obtained could be described by the following equations: $i_{\mathrm{ap}} / \mu \mathrm{A}=2.41 \times 10^{-4} \mathrm{v} / \mathrm{V} \mathrm{s}^{-1}+1.03 \times 10^{-6}$ $\left(\mathrm{R}^{2}=0.996\right)$ and $i_{\mathrm{ap}} / \mu \mathrm{A}=1.34 \times 10^{-4} \mathrm{v} / \mathrm{V} \mathrm{s}^{-1}+9.76 \times 10^{-7}\left(\mathrm{R}^{2}\right.$ $=0.990$ ) for HCT (insert, Fig. S1.I) and TRT (insert, Fig. S1.II), respectively. From this, it could be concluded that the charge transfer was controlled by the adsorption process [35]. Nevertheless, both compounds could be monitored at all the scan rates tested. A scan rate of $100 \mathrm{mV} \mathrm{s}^{-1}$ was employed in the subsequent experiments.

\subsection{Optimization of the method}

In order to be able to simultaneously detect HCT and TRT at low levels, investigation was made of the effects of $\mathrm{pH}$, accumulation potential, and accumulation time. Firstly, the behaviors of HCT and TRT were evaluated at $\mathrm{pH} 3-10$ in $0.10 \mathrm{~mol} \mathrm{~L}^{-1} \mathrm{~B}-\mathrm{R}$ buffer. For both diuretics, the highest $i_{\text {ap }}$ values were observed at $\mathrm{pH} 3$ and 4, with decreases at higher $\mathrm{pH}$ and the lowest values at $\mathrm{pH} 10$ (Fig. S2.I). The best peak separation for detection of both analytes was achieved at $\mathrm{pH}$ 4 , which was selected for use in the subsequent analyses. As the $\mathrm{pH}$ decreased, $E_{\text {ap }}$ shifted to more positive values for both HCT and TRT (Fig. S2.II), according to the following equations: $E_{\mathrm{ap}} / \mathrm{V}=-70.4 \times$ $10^{-3} \mathrm{pH}+1.30\left(\mathrm{R}^{2}=0.995\right)$ for HCT and $E_{\mathrm{ap}} / \mathrm{V}=-51.0 \times 10^{-3}$ $\mathrm{pH}+1.37\left(\mathrm{R}^{2}=0.994\right)$ for TRT. The results indicated the same $\mathrm{e}^{-} /$ $\mathrm{H}^{+}$ratios for oxidation of the diuretics $[15,34]$.

Since both diuretics showed charge transfer controlled by the adsorption process, preconcentration studies were performed using $50 \mu \mathrm{mol} \mathrm{L} \mathrm{L}^{-1}$ of HCT and TRT. The effect of the accumulation potential $\left(E_{\mathrm{ac}}\right)$ on $i_{\mathrm{ap}}$ was first evaluated in the range from 0.80 to $-0.40 \mathrm{~V}$, after stirring for $15 \mathrm{~s}$, as shown in Fig. S3.I. For both analytes, the highest $i_{\mathrm{ap}}$ was observed at $E_{\text {ac }}$ of $0.80 \mathrm{~V}$, which was therefore selected in the subsequent analyses. The effect of the accumulation time $\left(t_{\mathrm{ac}}\right)$ on $i_{\mathrm{ap}}$ was studied in the range from 15 to $70 \mathrm{~s}$, using $50 \mu \mathrm{mol} \mathrm{L}^{-1}$ of HCT and TRT (Fig. S3.II). For both compounds, $i_{\mathrm{ap}}$ increased as $t_{\mathrm{ac}}$ was increased from 15 to $40 \mathrm{~s}$. At longer $t_{\mathrm{ac}}$, a plateau was observed. Therefore, prior to each measurement, the solution was submitted to a preconcentration during $40 \mathrm{~s}$ at $E_{\mathrm{ac}}$ of $0.80 \mathrm{~V}$.

\subsection{Analytical performance}

Under optimized conditions of $\mathrm{pH}(4.0), E_{\mathrm{ac}}(0.80 \mathrm{~V})$, and $t_{\mathrm{ac}}(40 \mathrm{~s})$, linear sweep adsorptive stripping voltammograms (LSAdSV) for HCT and TRT were recorded in $0.10 \mathrm{~mol} \mathrm{~L}^{-1} \mathrm{~B}-\mathrm{R}$ buffer ( $\mathrm{pH} 4.0$ ), as shown in Fig. 3. For both HCT and TRT, two linear relationships were found in the concentration range from $1.0 \times 10^{-7}$ to $2.0 \times 10^{-5} \mathrm{~mol} \mathrm{~L}^{-1}$. The first was between $1.0 \times 10^{-7}$ and $5.0 \times 10^{-6} \mathrm{~mol} \mathrm{~L}^{-1}$, described by the equations: $i_{\mathrm{ap}} / \mu \mathrm{A}=0.565[\mathrm{HCT}] / \mu \mathrm{mol} \mathrm{L}^{-1}+2.06 \times 10^{-8}\left(\mathrm{R}^{2}\right.$ $=0.996)$ and $i_{\text {ap }} / \mu \mathrm{A}=0.895[\mathrm{TRT}] / \mu \mathrm{mol} \mathrm{L}{ }^{-1}+2.95 \times 10^{-7}\left(\mathrm{R}^{2}=\right.$ 0.997). The second linear relationship was between $5.0 \times 10^{-6}$ and 2.0 $\times 10^{-5} \mathrm{~mol} \mathrm{~L}^{-1}$, described by the equations: $i_{\mathrm{ap}} / \mu \mathrm{A}=0.412[\mathrm{HCT}] /$ $\mu \mathrm{mol} \mathrm{L} \mathrm{L}^{-1}+6.62 \times 10^{-7}\left(\mathrm{R}^{2}=0.997\right)$ and $i_{\text {ap }} / \mu \mathrm{A}=0.416[\mathrm{TRT}] /$ $\mu \mathrm{mol} \mathrm{L}{ }^{-1}+2.38 \times 10^{-6}\left(\mathrm{R}^{2}=0.999\right)$. The limits of detection (LD) and quantitation (LQ) were calculated using the expressions $\mathrm{LD}=3 \mathrm{std} / \mathrm{m}$ and $\mathrm{LQ}=10 \mathrm{std} / \mathrm{m}$, where $s t d$ is the standard deviation of 10 LSAdSVs obtained for the supporting electrolyte alone $\left(0.10 \mathrm{~mol} \mathrm{~L}^{-1} \mathrm{~B}-\mathrm{R}\right.$ buffer solution at $\mathrm{pH} 4.0$ ) and $m$ is the slope of the curve. The $\mathrm{LD}$ values were $2.8 \times 10^{-8}$ and $2.9 \times 10^{-8} \mathrm{~mol} \mathrm{~L}^{-1}$ and the corresponding $\mathrm{LQ}$ values were $9.5 \times 10^{-8}$ and $9.6 \times 10^{-8} \mathrm{~mol} \mathrm{~L}^{-1}$ for HCT and TRT, respectively. 


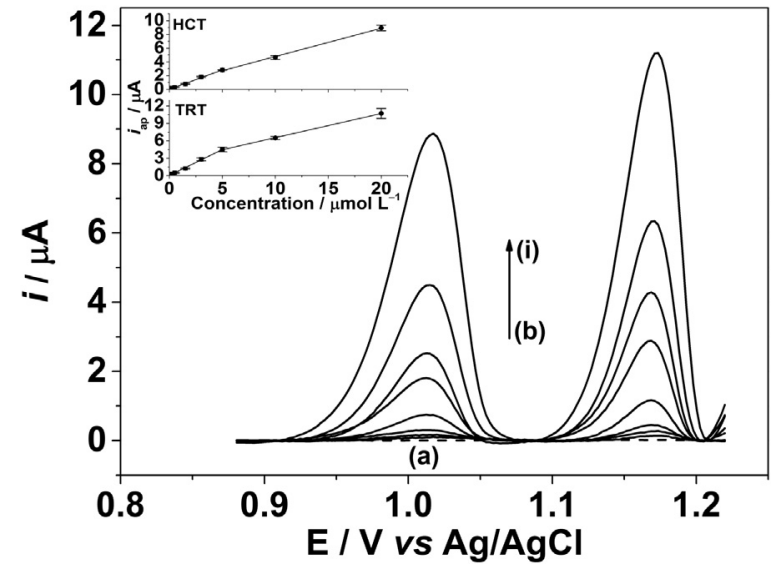

Fig. 3. LSAdSV using the GCE/MWCNT in $0.10 \mathrm{~mol} \mathrm{~L}^{-1} \mathrm{~B}-\mathrm{R}$ buffer (pH 4.0) (a) and with HCT and TRT concentrations of 0.100 (b), 0.200 (c), 0.500 (d), 1.00 (e), 5.00 (f), 10.0 (g), and $20.0 \mu \mathrm{mol} \mathrm{L}^{-1}$ (h). Figure insert: linear relationships for $i_{\text {ap }}$ vs. [HCT] and $i_{\text {ap }}$ vs. [TRT]. Conditions: $v=100 \mathrm{mV} \mathrm{s}^{-1} ; E_{\mathrm{ac}}=0.80 \mathrm{~V} ; t_{\mathrm{ac}}=40 \mathrm{~s}$.

Table 1 provides a comparison of the figures of merit of the proposed method and other techniques reported in the literature. The proposed sensor presented a lower limit of detection, compared to the values found elsewhere $[15,17,34,37]$. Although a lower limit of detection and higher linear range was obtained for the method described by Nezhadali [38], the novelty of the proposed sensor is that it enabled simultaneous determination of the analytes.

The repeatability of the method was evaluated using 10 analyses at concentrations of 0.500 and $15.0 \mu \mathrm{mol} \mathrm{L}^{-1}$ of HCT and TRT. The relative standard deviations obtained were $4.25 \%$ (HCT) and $5.02 \%$ (TRT) at $0.500 \mu \mathrm{mol} \mathrm{L}^{-1}$, and $5.98 \%$ (HCT) and $3.92 \%$ (TRT) at $15.0 \mu \mathrm{mol} \mathrm{L}^{-1}$, indicating that the proposed electrode was not poisoned during consecutive analyses, since the solution was stirred between the measurements.

\subsection{Interference study}

In order to evaluate possible interferences in the $i_{\text {ap }}$ of the analytes, evaluation was made of the effects of the possible interferents glucose (GLI), urea (UR), furosemide (FUR), ascorbic acid (AA), uric acid (UA), creatinine (CR), and bumetanide (BMT), using concentrations ranging from 0.1 -fold to 10 -fold the concentrations of HCT and TRT (in this case between 0.3 and $30 \mu \mathrm{mol} \mathrm{L}^{-1}$ ). Table 2 shows the concentration range studied for each possible interferent and the percentage effects on the $i_{\text {ap }}$ of HCT and TRT. In the potential range studied, no significant effects on $i_{\text {ap }}$ were observed for GLI, UR, AA, UA, and CR, at any of the concentrations tested, indicating that these substances did not interfere in the responses of the analytes. FUR and BMT showed oxidation peaks in the potential window employed, at 0.965 and $1.13 \mathrm{~V}$ for FUR and at 0.876 and $0.948 \mathrm{~V}$ for BMT. In the case of FUR, at concentrations in the
Table 2

Results of interference assays employing glucose, urea, furosemide, ascorbic acid, uric acid, creatinine, and bumetanide.

\begin{tabular}{llll}
\hline Interfering & Analyte & Concentration & $\%$ signal \\
\hline \multirow{2}{*}{ GLI } & HCT & $0.30-30$ & $92.1-109$ \\
& TRT & $0.30-30$ & $90.8-99.1$ \\
UR & HCT & $0.30-30$ & $98.8-108$ \\
& TRT & $0.30-30$ & $90.4-102$ \\
FUR & HCT & $0.30-6.0$ & $91.6-106$ \\
& TRT & $0.30-6.0$ & $90.4-106$ \\
AA & HCT & $0.30-30$ & $92.4-109$ \\
& TRT & $0.30-30$ & $96.4-109$ \\
UA & HCT & $0.30-30$ & $90.7-103$ \\
& TRT & $0.30-30$ & $93.9-109$ \\
CR & HCT & $0.30-30$ & $90.5-100$ \\
& TRT & $0.30-30$ & $90.7-111$ \\
BMT & HCT & $0.30-30$ & $94.2-108$ \\
& TRT & $0.30-15$ & $92.8-111$ \\
\hline
\end{tabular}

range from 0.30 to $6.0 \mu \mathrm{mol} \mathrm{L} \mathrm{L}^{-1}$, there were no significant alterations in the $i_{\mathrm{ap}}$ values for HCT and TRT. At higher concentrations, the oxidation peak of FUR began to interfere in the oxidation of the analytes. BMT showed no interference in the $i_{\text {ap }}$ of HCT, despite the existence of an oxidation peak in the range employed. However, BMT showed interference in the analysis of TRT when the interferent was present at a concentration 5-fold higher than the TRT concentration (when the BMT concentration exceeded $15 \mu \mathrm{mol} \mathrm{L}^{-1}$ ).

\subsection{Application of the GCE/MWCNT sensor}

The GCE/MWCNT sensor was applied in the analysis of three types of sample: artificial urine, since HCT and TRT are regulated and monitored by the World Anti-Doping Agency (WADA) [39], and in tap water and water treatment plant water, due to concerns about the release of these drugs and their presence in wastewater [40]. In all cases, the concentrations obtained were close to the fortified concentrations (Table 3). Application of the student's $t$-test [41] showed that there were no significant differences (at a 95\% confidence level) between the fortified and recovered concentrations. The results demonstrated the satisfactory applicability of the method for the simultaneous determination of HCT and TRT.

\subsection{Comparison with the HPLC-DAD method and application using a hemodialysis sample}

After optimization and application of the GCE/MWCNT sensor, an HPLC-DAD method was developed for the determination of HCT and TRT (based on modified literature method [42]), for comparison with the proposed electroanalytical method.

The best chromatographic conditions for separation of the diuretics were found using a mobile phase consisting of methanol and

Table 1

Comparison between the figures of merit of the proposed GCE/MWCNT method and other techniques reported in the literature for the determination of HCT and TRT.

\begin{tabular}{|c|c|c|c|c|c|}
\hline Analyte & Electrode & Technique & Concentration range $\left(\mathrm{mol} \mathrm{L}^{-1}\right)$ & $\mathrm{LD}\left(\mathrm{mol} \mathrm{L}^{-1}\right)$ & Reference \\
\hline \multirow[t]{3}{*}{ TRT } & ${ }^{\mathrm{a}}$ GECE/MPs-To & SWV & $5.00 \times 10^{-7}$ to $9.98 \times 10^{-5}$ & $1.4 \times 10^{-7}$ & [15] \\
\hline & ${ }^{\mathrm{b}} \mathrm{MIPs} / \mathrm{MWCNTs} / \mathrm{PGE}$ & DPV & $8.00 \times 10^{-8}$ to $2.65 \times 10^{-4}$ & $3.3 \times 10^{-9}$ & [38] \\
\hline & GCE/MWCNT & LSAdSV & $1 \times 10^{-7}$ a $2 \times 10^{-5}$ & $2.8 \times 10^{-8}$ & This work \\
\hline \multirow[t]{4}{*}{ HCT } & ${ }^{\mathrm{c}} \mathrm{BDDE}$ & DPV & $5.10 \times 10^{-7}$ to $1.87 \times 10^{-5}$ & $3.7 \times 10^{-7}$ & [17] \\
\hline & ${ }^{\mathrm{d}} \mathrm{NMN}$ & LSV & $1.39 \times 10^{-5}$ to $1.67 \times 10^{-4}$ & $7.9 \times 10^{-6}$ & [37] \\
\hline & BDDE & SWV & $4.0 \times 10^{-6}$ to $8.3 \times 10^{-5}$ & $1.0 \times 10^{-6}$ & [34] \\
\hline & GCE/MWCNT & LSAdSV & $1 \times 10^{-7}$ to $2 \times 10^{-5}$ & $2.9 \times 10^{-8}$ & This work \\
\hline
\end{tabular}

\footnotetext{
${ }^{\text {a }}$ GECE/MPs-To: Graphite epoxy composite electrode modified by tosyl-functionalized magnetic particles.

b MIPs/MWCNTs/PGE: Molecularly imprinted polymer/multi-walled carbon nanotubes immobilized pencil graphite electrode.

c BDDE: Boron-doped diamond electrode.

${ }^{\mathrm{d}}$ NMN: nickel hydroxide modified nickel electrode.
} 
Table 3

Results of application of the GCE/MWCNT technique for the analysis of tap water, water treatment plant water, and artificial urine.

\begin{tabular}{lll}
\hline Tap water sample & & \\
\hline Analyte & HCT & TRT \\
\hline Added $\left(\mu \mathrm{mol} \mathrm{L}^{-1}\right)$ & 3.00 & 3.00 \\
Found $\left(\mu \mathrm{mol} \mathrm{L}^{-1}\right)$ & $3.08 \pm 0.0805$ & $3.12 \pm 0.167$ \\
$t$ calc. & 0.827 & 1.21 \\
Water treatment plant sample & & \\
Analyte & HCT & TRT \\
Added $\left(\mu \mathrm{mol} \mathrm{L}^{-1}\right)$ & 15.0 & 15.0 \\
Found $\left.\mu \mathrm{mol} \mathrm{L}^{-1}\right)$ & $15.7 \pm 1.32$ & $13.4 \pm 1.21$ \\
$t$ calc. & 0.997 & 2.22 \\
Artificial urine sample & & \\
Analyte & HCT & TRT \\
Added $\left(\mu \mathrm{mol} \mathrm{L}^{-1}\right)$ & 8.40 & 9.87 \\
Found $\left.\mu \mathrm{mol} \mathrm{L}^{-1}\right)$ & $7.84 \pm 0.254$ & $9.82 \pm 0.690$ \\
$t$ calc. & 3.78 & 0.124 \\
\hline
\end{tabular}

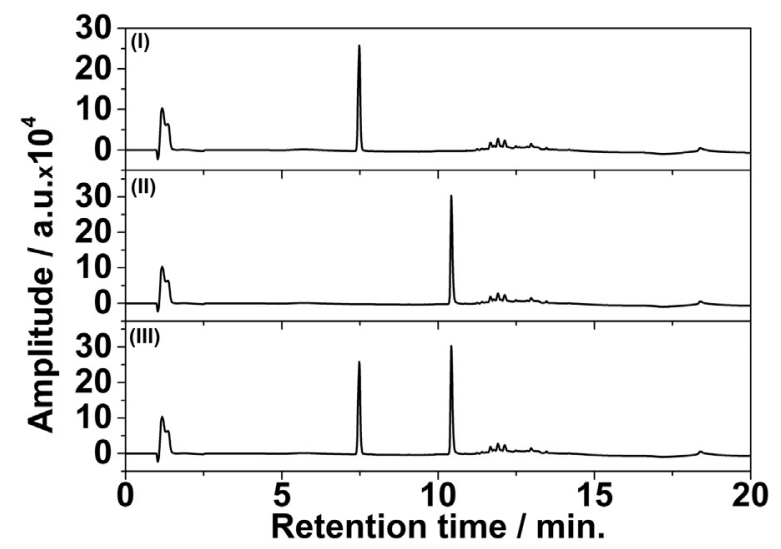

Fig. 4. Chromatograms for HCT (I), TRT (II), and HCT + TRT (III). Conditions: $[\mathrm{HCT}]=$ $5.04 \times 10^{-5} \mathrm{~mol} \mathrm{~L}^{-1}$; [TRT] $=5.92 \times 10^{-5} \mathrm{~mol} \mathrm{~L}^{-1}$.

$0.01 \mathrm{~mol} \mathrm{~L}^{-1}$ acetate buffer ( $\mathrm{pH} 5.6$ ), in gradient mode at a flow rate of $1.2 \mathrm{~mL} \mathrm{~min}^{-1}$, with the column heated at $35{ }^{\circ} \mathrm{C}$. Both diuretics were detected at a wavelength of $227 \mathrm{~nm}$. As shown in Fig. 4.I and .II, injections of the individual compounds under optimized conditions resulted in retention times $\left(t_{\text {ret }}\right)$ of $7.46 \mathrm{~min}$ (HCT) and $10.4 \mathrm{~min}$ (TRT). The same retention times were obtained for simultaneous injection of the two diuretics (Fig. 4.III).

The analytical curve for HCT presented linearity between $8.40 \times 10^{-6}$ and $1.68 \times 10^{-4} \mathrm{~mol} \mathrm{~L}^{-1}$, described by the equation: A / a.u. $=2.43 \times 10^{10}[\mathrm{HCT}] / \mathrm{mol} \mathrm{L}^{-1}+28901.2\left(\mathrm{R}^{2}=0.999\right)$. For TRT, linearity was obtained between $5.92 \times 10^{-6}$ and $3.95 \times$ $10^{-4} \mathrm{~mol} \mathrm{~L}^{-1}$, described by the equation: A / a.u. $=2.30 \times 10^{10}$ [TRT] $/ \mathrm{mol} \mathrm{L}^{-1}+16083.2\left(\mathrm{R}^{2}=0.999\right)$. The calculated $\mathrm{LD}$ values were 2.3 $\times 10^{-6}$ and $1.8 \times 10^{-6} \mathrm{~mol} \mathrm{~L}^{-1}$ for HCT and TRT, respectively. The repeatability of the method was assessed using the relative standard deviations (RSDs) of inter-day and intra-day measurements. For HCT at concentrations of $8.40 \times 10^{-6}, 16.8 \times 10^{-6}$, and $33.6 \times$ $10^{-6} \mathrm{~mol} \mathrm{~L}^{-1}$, the RSD values were $2.20 \%, 0.880 \%$, and $0.890 \%$ (interday) and $4.03 \%, 2.15 \%$, and $0.470 \%$ (intra-day), respectively. For TRT at concentrations of $5.92 \times 10^{-6}, 19.7 \times 10^{-6}$, and $39.5 \times$ $10^{-6} \mathrm{~mol} \mathrm{~L}^{-1}$, the RSD values were $1.83 \%, 0.430 \%$, and $0.400 \%$ (interday) and $5.01 \%, 1.93 \%$, and $0.580 \%$ (intra-day), respectively.

After the development of the chromatographic method, the GCE/ MWCNT and HPLC-DAD methods were compared for analysis of a hemodialysis sample. Similar HCT and TRT concentrations were obtained with the two methods (Table 4). Application of the Student's $t$-test (paired values) resulted in values of $t$ of 2.18 (HCT) and 1.23 (TRT), which were lower than $t_{\text {crit }}(4.30)$ [41]. This showed that there were no
Table 4

Determination of HCT and TRT in a hemodialysis sample using the proposed GCE/ MWCNT method and the HPLC-DAD technique.

\begin{tabular}{lllll}
\hline Analyte & HCT & & TRT & \\
\hline Method & GCE/MWCNT & HPLC-DAD & GCE/MWCNT & HPLC-DAD \\
$\begin{array}{c}\text { Found values } \\
\left(\mu \mathrm{mol} \mathrm{L}^{-1}\right)\end{array}$ & $15.5 \pm 0.108$ & $15.2 \pm 0.100$ & $14.3 \pm 0.0926$ & $14.3 \pm 0.129$ \\
& & & & \\
\hline
\end{tabular}

$\mathrm{n}=3$.

significant differences (at a 95\% confidence level) between the concentrations obtained using the proposed voltammetric method and the HPLC-DAD method.

The results demonstrated that the voltammetric method based on GCE/MWCNT could be used for the simultaneous determination of HCT and TRT in different types of sample, offering rapidity, low cost, low levels of detection, and no requirement for the organic solvents employed in chromatographic methods.

\section{Conclusions}

The findings of this work showed that a glassy carbon electrode modified with carbon nanotubes could provide excellent performance in the simultaneous determination of diuretics. The modification of the electrode resulted in a decrease in the charge transfer resistance and an increase in the analyte signal intensity, compared to the unmodified electrode. The technique enabled simultaneous determination of HCT and TRT, unlike most electroanalytical methods, where only individual determinations are possible. The method showed a wide linear range, low detection limits, and excellent performance in the simultaneous determination of HCT and TRT in tap water, water treatment plant water, and artificial urine samples. The detection limit of the electrochemical method was lower than that of the comparative HPLC-DAD method, and there was no significant difference (at a 95\% level of confidence) between the methods when they were applied for analysis of a hemodialysis sample.

\section{Acknowledgements}

Financial support for this research was provided by the Brazilian funding agencies CNPq (grant numbers 153169/2014-1, 446245/20143 , and 465571/2014-0) and FAPESP (grant numbers 2014/50945-1, 2015/18109-4, and 2015/12998-1).

\section{Appendix A. Supplementary material}

Supplementary data associated with this article can be found in the online version at http://dx.doi.org/10.1016/j.talanta.2017.11.071.

\section{References}

[1] N. Sekercioglu, H. Balci, M. Pekpak, Procalcitonin and malondialdehyde as markers of inflammation in hemodialysis patients, J. Clin. Anal. Med. 8 (2017) 346-350.

[2] A.S. Levey, J. Coresh, Chronic kidney disease, Lancet 379 (2012) 165-180.

[3] E.J. Santos, E.B. Fantin, R.E. Paixão, A.B. Herrmann, R.E. Sturgeon, Spectrophotometric determination of aluminium in hemodialysis water, J. Braz. Chem. Soc. 26 (2015) 2384-2388.

[4] P.C. do Nascimento, A.L.B. Rohlfes, D. Bohrer, L.M. de Carvalho, E.J. Pilau, HPLC based method using sample precolumn cleanup for the determination of triazines and thiolcarbamates in hemodialysis saline solutions, Talanta 65 (2004) 211-216.

[5] P.C. Nascimento, C.L. Jost, M.V. Guterres, L.D. Del' Fabro, L.M. de Carvalho, D. Bohrer, Simultaneous determination of $\mathrm{Al}(\mathrm{III})$ and $\mathrm{Fe}(\mathrm{III})$ in post-hemodialysis fluids by spectrophotometry and multivariate calibration, Talanta 70 (2006) $540-545$.

[6] P.C. do Nascimento, C.L. Jost, L.M. de Carvalho, D. Bohrer, A. Koschinsky, Voltammetric determination of Se(IV) and Se(VI) in saline samples-studies with seawater, hydrothermal and hemodialysis fluids, Anal. Chim. Acta 648 (2009) $162-166$.

[7] P.C. Nascimento, A.B. Schneider, D. Bohrer, L.M. de Carvalho, C.L. Jost, Sequential voltammetric determination of chromium, thallium, cadmium, lead, copper and 
antimony in saline hemodialysis concentrates using electrolyte $\mathrm{pH}$ gradient, J. Braz. Chem. Soc. 22 (2011) 820-827.

[8] A. Guarda, P.C. Nascimento, D. Bohrer, L.M. de Carvalho, A.B. Schneider, D. Dias, B. Wiethan, Voltammetric determination of mercury(II) in hemodialysis polyelectrolyte solutions using Bi-glassy carbon electrodes modified with L-cysteine, Anal. Methods 5 (2013) 4739-4745.

[9] J.K. Inrig, Antihypertensive agents in hemodialysis patients: a current perspective, Semin. Dial. 23 (2010) 290-297.

[10] J. Vojta, A. Jedlička, P. Coufal, L. Janečková, A new, rapid, stability-indicating UPLC method for separation and determination of impurities in amlodipine besylate, valsartan and hydrochlorothiazide in their combined tablet dosage form, J. Pharm. Biomed. Anal. 109 (2015) 36-44.

[11] H. Woo, J.W. Kim, K.M. Han, J.H. Lee, I.S. Hwang, J.H. Lee, J. Kim, S.J. Kweon, S. Cho, K.R. Chae, S.Y. Han, J. Kim, Simultaneous analysis of 17 diuretics in dietary supplements by HPLC and LC-MS/MS, Food Addit. Contam. Part A 30 (2013) 209-217.

[12] M.H. Ferreira, J.W.B. Braga, M.M. Sena, Development and validation of a chemometric method for direct determination of hydrochlorothiazide in pharmaceutical samples by diffuse reflectance near infrared spectroscopy, Microchem. J. 109 (2013) 158-164.

[13] S. Hillaert, W. Van den Bossche, Simultaneous determination of hydrochlorothiazide and several angiotensin-II-receptor antagonists by capillary electrophoresis, J. Pharm. Biomed. Anal. 31 (2003) 329-339.

[14] H. Heli, J. Pishahang, H.B. Amiri, N. Sattarahmady, Synthesis of nickel nanowrinkles and its application for the electrocatalytic oxidation and sensitive detection of hydrochlorothiazide, Microchem. J. 130 (2017) 205-212.

[15] F.F. Hudari, B.F. da Silva, M.I. Pividori, M.V.B. Zanoni, Voltammetric sensor based on magnetic particles modified composite electrode for determination of triamterene in biological sample, J. Solid State Electrochem. 20 (2016) 2491-2501.

[16] F. Tian, H. Li, M. Li, C. Li, Y. Lei, B. Yang, A tantalum electrode coated with graphene nanowalls for simultaneous voltammetric determination of dopamine, uric acid, L-tyrosine, and hydrochlorothiazide, Microchim. Acta 184 (2017) 1611-1619.

[17] C.A.R. Salamanca-Neto, A.P.P. Eisele, V.G. Resta, J. Scremin, E.R. Sartori, Differential pulse voltammetric method for the individual and simultaneous determination of antihypertensive drug metoprolol and its association with hydrochlorothiazide in pharmaceutical dosage forms, Sens. Actuators B Chem. 230 (2016) 630-638.

[18] G. Yildiz, N. Oztekin, A. Orbay, F. Senkal, Voltammetric determination of nitrite in meat products using polyvinylimidazole modified carbon paste electrode, Food Chem. 152 (2014) 245-250.

[19] G. Yildiz, U. Tasdoven, N. Menek, Electrochemical characterization of luminol and its determination in real samples, Anal. Methods 6 (2014) 7809-7813.

[20] Z. Wang, Y. Yao, H. Zhang, J. Zhang, W. Ding, Z. Liu, J. Xu, Y. Wen, Highly waterstable PEDOT:PSS composite electrode decorated with polyvinylpyrrolidone and carbon nanotubes for sensitive detection of Eugenol, Int. J. Electrochem. Sci. 10 (2015) 6997-7012.

[21] G. Yildiz, Z. Aydogmus, M.E. Cinar, F. Senkal, T. Ozturk, Electrochemical oxidation mechanism of eugenol on graphene modified carbon paste electrode and its analytical application to pharmaceutical analysis, Talanta 173 (2017) 1-8.

[22] C. Pérez-Ràfols, N. Serrano, J.M. Díaz-Cruz, C. Ariño, M. Esteban, Glutathione modified screen-printed carbon nanofiber electrode for the voltammetric determination of metal ions in natural samples, Talanta 155 (2016) 8-13.

[23] S. Shahrokhian, M. Ghalkhani, H. Balotf, R. Salimian, Application of glassy carbon electrode modified with a carbon nanoparticle/melamine thin film for voltammetric determination of raloxifene, J. Electroanal. Chem. 780 (2016) 126-133.

[24] F.F. Hudari, L.C. de Almeida, B.F. da Silva, M.V.B. Zanoni, Voltammetric sensor for simultaneous determination of p-phenylenediamine and resorcinol in permanent hair dyeing and tap water by composite carbon nanotubes/chitosan modified electrode, Microchem. J. 116 (2014) 261-268.

[25] M.M. Pedroso, M.V. Foguel, D.H.S. Silva, M. del, P.T. Sotomayor, H. Yamanaka, Electrochemical sensor for dodecyl gallate determination based on electropolymerized molecularly imprinted polymer, Sens. Actuators B Chem. 253 (2017) $180-186$.

[26] B.C. Huayhuas-Chipana, M.V. Foguel, L.M. Gonçalves, M.D.P.T. Sotomayor, Modified screen-printed electrode for the FIA-amperometric determination of 2nitro-p-phenylenediamine, Microchem. J. 131 (2017) 92-97.

[27] S. Iijima, Helical microtubules of graphitic carbon, Nature 354 (1991) 56-58.

[28] I. Mazov, V.L. Kuznetsov, I.A. Simonova, A.I. Stadinichenko, A.V. Ishchenko, Oxidation behavior of multiwall carbon nanotubes with different diameters and morphology, Appl. Surf. Sci. 258 (2012) 6272-6280.

[29] M. Cittan, S. Koçak, A. Celik, K. Dost, Determination of oleuropein using multiwalled carbon nanotube modified glassy carbon electrode by adsorptive stripping square wave voltammetry, Talanta 159 (2016) 148-154.

[30] A. Babaei, A.R. Taheri, M. Afrasiabi, A multi-walled carbon nanotube-modified glassy carbon electrode as a new sensor for the sensitive simultaneous determination of paracetamol and tramadol in pharmaceutical preparations and biological fluids, J. Braz. Chem. Soc. 22 (2011) 1549-1558.

[31] K. Sipa, M. Brycht, A. Leniart, P. Urbaniak, A. Nosal-Wiercińska, B. Pałecz, S. Skrzypek, $\beta$-Cyclodextrins incorporated multi-walled carbon nanotubes modified electrode for the voltammetric determination of the pesticide dichlorophen, Talanta 176 (2018) 625-634.

[32] A. Wong, C.A. Razzino, T.A. Silva, O. Fatibello-Filho, Square-wave voltammetric determination of clindamycin using a glassy carbon electrode modified with graphene oxide and gold nanoparticles within a crosslinked chitosan film, Sens. Actuators B Chem. 231 (2016) 183-193.

[33] N. Laube, B. Mohr, A. Hesse, Laser-probe-based investigation of the evolution of particle size distributions of calcium oxalate particles formed in artificial urines, $\mathrm{J}$ Cryst. Growth 233 (2001) 367-374.

[34] M.C.G. Santos, C.R.T. Tarley, L.H. Dall'Antonia, E.R. Sartori, Evaluation of borondoped diamond electrode for simultaneous voltammetric determination of hydrochlorothiazide and losartan in pharmaceutical formulations, Sens. Actuators B Chem. 188 (2013) 263-270.

[35] A.J. Bard, L.R. Faulkner, Electrochemical Methods Fundamentals and Applications, 2nd ed, Wiley, New York, 2001.

[36] M.M. Baizer, H. Lund, Organic Electrochemistry - An Introduction and a guide, 2nd ed., New York, 1983.

[37] W.B.S. Machini, D.N. David-Parra, M.F.S. Teixeira, Electrochemical investigation of the voltammetric determination of hydrochlorothiazide using a nickel hydroxide modified nickel electrode, Mater. Sci. Eng. C 57 (2015) 344-348.

[38] A. Nezhadali, M. Mojarrab, Fabrication of an electrochemical molecularly imprinted polymer triamterene sensor based on multivariate optimization using multiwalled carbon nanotubes, J. Electroanal. Chem. 744 (2015) 85-94.

[39] The World Anti-Doping Code Prohibited List Non-Approved Substances Anabolic Agents, 〈https://www.wada-ama.org/sites/default/files/resources/files/2016-09. 29_-_wada_prohibited_list_2017_eng_final.pdf〉 (Accessed 31 July 2017), 2017.

[40] M.C. Campos-Mañas, P. Plaza-Bolaños, J.A. Sánchez-Pérez, S. Malato, A. Agüera, Fast determination of pesticides and other contaminants of emerging concern in treated wastewater using direct injection coupled to highly sensitive ultra-high performance liquid chromatography-tandem mass spectrometry, J. Chromatogr. A 1507 (2017) 84-94.

[41] J.C. Miller, J.N. Miller, Statistics for Analytical Chemistry, 2nd ed., Ellis Horwood Limited, England, 1988.

[42] M. Smajić, Z. Vujić, N. Mulavdić, J. Brborić, An improved HPLC method for simultaneous analysis of Losartan potassium and hydrochlorothiazide with the aid of a chemometric protocol, Chromatographia 76 (2013) 419-425. 